\title{
THE ROLE OF THE PERFORMANCE DASHBOARD IN THE MANAGEMENT OF MODERN ENTERPRISES
}

\author{
Simona Elena Dragomirescu \\ "Vasile Alecsandri” University of Bacău \\ dragomirescu@ub.ro \\ Daniela Cristina Solomon \\ “Vasile Alecsandri” University of Bacău \\ daniela.solomon@ub.ro
}

\begin{abstract}
Nowadays, the management of any modern enterprise requires a real-time information system which should allow the continuous and quick display of the data which is critical in order to control the company in the current economic context. The performance dashboard is such an information system. It is made up of quantity, quality or financial management indicators or, in other words, of greatly significant pieces of information put together, which have immediate meaning for the person reading it. We must take into consideration the fact that the data is extremely dense and it is in continuous movement, being used in forming plans, in supporting decisions and in achieving control. The quality of decision and the achievement of performance depend on the quality of the information supplied. That is the reason why, in order to be useful for the decision-making process, the information must be reliable, up-to-date, complete, pertinent and accessible for the decision makers. Thus, an efficient performance dashboard is the one that allows the assessment and management of performance by means of the progress methods set in the strategy, and that helps the management face the changes and the challenges in the current economic climate.
\end{abstract}

\section{Keywords}

dashboard; enterprise management; performance and pilotage indicators; control performance

\section{JEL Classification}

M41

It is not necessary to have a Boeing 747 dashboard in order to run a company... It is enough to focus your attention on a handful of indicators... provided that they should be well chosen Nathalie Mourlot (Tableaux de bord)

\section{General information concerning the performance dashboards. Use, functions, principles}

The performance dashboard developed on the level of the enterprise encloses global, aggregate information which describes the evolution of the enterprise strategic orientation. The evolution of activities specific to different fields of responsibility is described in the inventory dashboard. The performance dashboards drawn up for the lower levels of hierarchy will be consolidated and condensed into the dashboards for the upper levels of hierarchy. For the highest level of hierarchy, the dashboard will include a general view on the enterprise management, which will be a presentation of the achievements reported to the action plan, and will have as a main objective the control of management and the analysis of the economic and social indicators (Tabără et al, 2009).

The unity of the dashboards, considering the characteristics of modern management, can be suggestively presented as follows: 


Characteristics of modern
management

\section{Figure 1 Dashboard “offer” considering the characteristics of the modern management}

Source: Albu, N., Albu, C. (2003), Instrumente de management ale performanței, Volume II Control de gestiune, Economic Publishing House, Bucharest, p. 126

The performance dashboard seems to be a tool for controlling the action and the responsibilities. From this point of view, its main virtue is that it produces a piece of information almost instantaneously and makes it possible for the main people in charge to act in due time.

Thus, we can point out the main functions of the dashboard: 


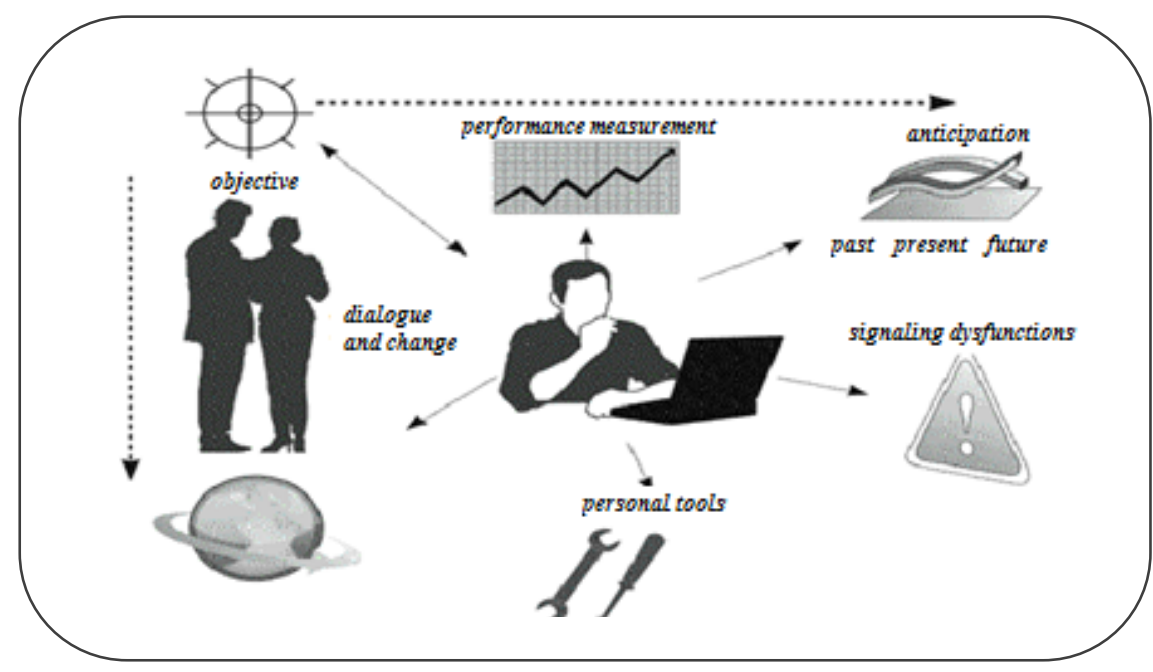

Figure 2 The functions of the dashboard

Source: Fernandez, A. (2008) Les nouveaux tableaux de bord des managers. Le projet décisionnel en totalité, on the Edit Organisation, 4 th édition, http://www.nodesway.com/methode/methode_GIMSI_ concevoir_le_tableau_de_bord.htm

- informing the manager on the state of the department he/she is running;

- warning on any unfavourable situations, on any deviation from normality;

- assessing the results achieved in the endeavour to reach the objectives and, implicitly, assessing the quality of the decisions made and of the actions taken in order to make these decisions operational;

- the decision-making function, meaning that pertinent information sent in due time to the managers placed on different levels in the company chain of command allow them to substantiate and make proper decisions. (Caraiani \& Dumitrana (coord.) et al, 2005)

In order to fulfil these functions, the management dashboard must cover the following principles:

- its architecture must coincide with the structure of the enterprise; if the action is drawn up according to the chain of command, the architecture of the information system will have to follow the management structure;

- in order to achieve the desired dashboard, threshold values will have to be set for each indicator, values which have to be considered by those in charge; the information that must be provided will have to be defined, and the rules using those indicators will have to be determined;

- for each level, the dashboard must also include some collateral information for a better fulfilment of the tasks assigned to the responsibility centres;

- the dashboard must have an open perspective on the competition, it must take into consideration the performance of the best competitor as reference in guiding the company's actions;

- as it is a decision-making tool, the design and the content of the dashboard must be adapted to the personality of its user;

- a high-performance dashboard supplies in real time indicators, as well as a history of them, which should allow the anticipation of events and the activation of the ones in charge in due time;

- the periodicity of indicators must be adapted to the frequency of analysis and to the action capability of the ones in charge. This periodicity must allow for a timely reaction. 
- the indicators listed in the dashboard for the supervisor must coincide with the ones for the subordinates.

\section{The dashboard building process}

The whole process of drawing up the dashboard of a company involves the following stages:

Table 1 The construction stages of the dashboard

\begin{tabular}{|c|c|}
\hline Stages & Description of stages \\
\hline $\begin{array}{l}\text { 1. Drawing up the } \\
\text { management flow } \\
\text { chart and naming the } \\
\text { ones in charge of } \\
\text { devising and ensuring } \\
\text { the logistics necessary } \\
\text { for the dashboard to } \\
\text { be functional }\end{array}$ & $\begin{array}{l}\text { - the dashboard must follow the existing } \\
\text { organizational structure, and not the other way } \\
\text { round; } \\
\text { - the organizational structure must be clear and } \\
\text { coherent; } \\
\text { - in order to draw up the management flow chart, one } \\
\text { must set the responsibilities and the functional } \\
\text { informal hierarchical chain; set the appropriate } \\
\text { methods; assign the responsibilities according to the } \\
\text { objectives set. }\end{array}$ \\
\hline $\begin{array}{l}\text { 2. Setting the objectives } \\
\text { (the key points in the } \\
\text { decision-making } \\
\text { process) }\end{array}$ & $\begin{array}{l}\text { - the objectives pertain to the enterprise itself as well } \\
\text { as to the tasks of drawing up, filling out, sending } \\
\text { and using the dashboard; } \\
\text { - } \text { they are expressed using quantitative and/or } \\
\text { qualitative indicators for the enterprise as well as } \\
\text { indicators specific to the dashboard; } \\
\text { - } \text { the objectives underline the purpose for which they } \\
\text { were drafted and the enterprise must work as a } \\
\text { whole as well as on the level of each one of its } \\
\text { procedural and structural units; } \\
\text { setting some key-points in the decision-making } \\
\text { process aims at selecting the main tasks and } \\
\text { objectives; starting from the strategic objective of } \\
\text { the enterprise, the sub-objectives are set according } \\
\text { to the type of centre (cost centre, profit centre etc.); }\end{array}$ \\
\hline $\begin{array}{l}\text { 3rafting a list of tasks, } \\
\text { competences and } \\
\text { responsibilities }\end{array}$ & $\begin{array}{l}\text { - specific for each functional and operational } \\
\text { department; } \\
\text { - the purpose is to allow the personnel to receive the } \\
\text { information necessary for achieving their own } \\
\text { objectives as well as the objectives of the other } \\
\text { departments; }\end{array}$ \\
\hline 4. Setting the indicators & $\begin{array}{l}\text { - choosing the indicators has as a purpose to } \\
\text { determine if the objectives are achieved; an } \\
\text { important role is that of the indices (relative values } \\
\text { of the reports between two quality or quantity } \\
\text { indicators); } \\
\text { - it is recommended to keep a limited number of } \\
\text { indicators, as a too great amount of information } \\
\text { risks to become inefficient; } \\
\text { - the indicators must follow the key-points in the } \\
\text { enterprise management, must stir the awareness of }\end{array}$ \\
\hline
\end{tabular}




\begin{tabular}{|c|c|}
\hline Stages & Description of stages \\
\hline & $\begin{array}{l}\text { the ones in charge and orient the action on short } \\
\text { term; }\end{array}$ \\
\hline $\begin{array}{l}\text { 5. Collecting the } \\
\text { information based on } \\
\text { which the indicators } \\
\text { are calculated }\end{array}$ & $\begin{array}{l}\text { - the information based on which the indicators are } \\
\text { determined can be collected from different sources; } \\
\text { for example, from the cash/management accounts, } \\
\text { from statistics and studies carried out on different } \\
\text { sectors, from predictions, etc. } \\
\text { - for some of the indicators, there is available } \\
\text { information and consequently they can be } \\
\text { determined; a problem occurs when there is a lack } \\
\text { of updated information or there is no immediate } \\
\text { source that can be used - in this case, based on } \\
\text { studying the existing data, we resort to estimations } \\
\text { and extrapolations. }\end{array}$ \\
\hline $\begin{array}{l}\text { 6. Typing the dashboard } \\
\text { and using the } \\
\text { information }\end{array}$ & 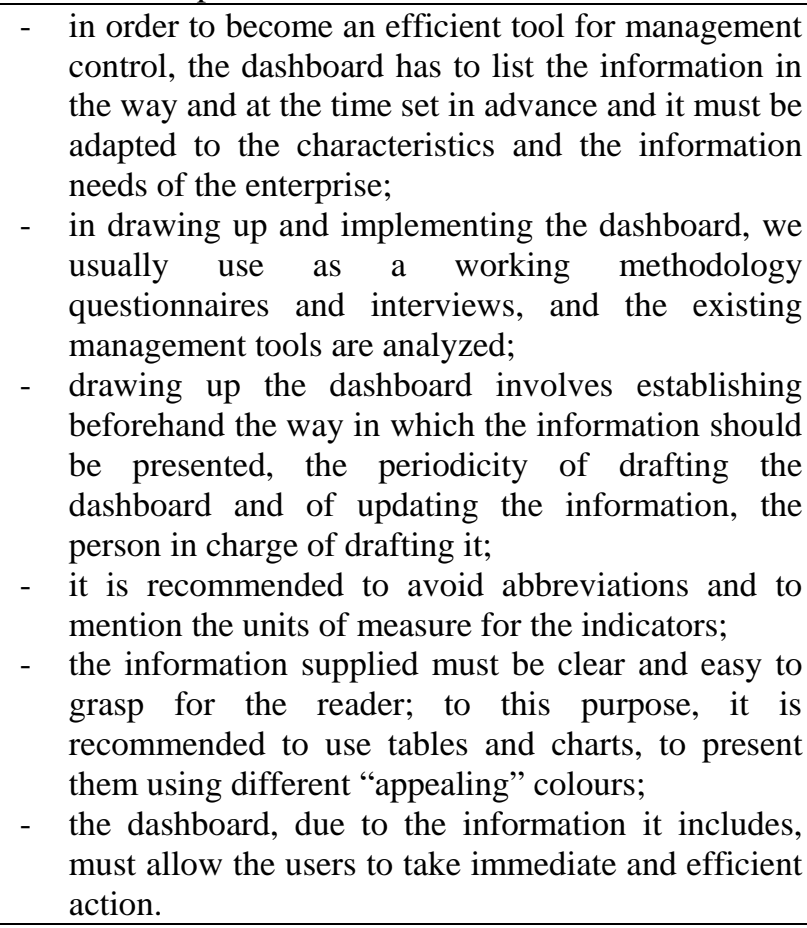 \\
\hline
\end{tabular}

Source: Processing according to Caraiani, C., Dumitrana, M. (coord.) et al (2005), Contabilitate de gestiune şi control de gestiune, InfoMega Publishing House, Bucharest, pp. 433-437

The purpose of the performance dashboard in reached by obeying certain principles during the construction stage:

- coherence - it means that the information offered by the performance dashboard should follow the company's chain of command and the departments with identical functions placed on the same level in this chain of command should have the same performance indicators, the same definition of the indicators and the same source of information;

- pertinence - the indicators chosen (the critical ones) should reflect the key points in the performance of the centres, and the data on which these indicators are based should emphasize correctly the achievement of the command centre objectives; 
- frequency - it refers to the deadline for drafting the dashboard and to the speed in disseminating it, and it depends on the duration of the life cycle of the decisions and the actions taken in that centre;

- efficiency - it indicates the dashboard capability of leading to action, to analysing, of correcting and interpreting the deviations as well as taking corrective measures if necessary;

- standards - they are the objectives, the results of the previous actions and the hypotheses based on which the deviations are set and analysed.

\section{Types of performance dashboards used in enterprises}

In the specialized literature and in the economic practice there are many types of dashboards, all based on different classification criteria according to the desired information - limited, referring to a certain procedural or structural part, or broad, referring to all the aspects investigated.

We can narrow the range of dashboards to three common types:

- strategic,

- tactical,

- operational.

Strategic dashboards list information with a high degree of processing, ensure a quick overview on the way the organization works and make it easy to draw certain conclusions, following all the functions of the economic entity in a balanced way (Popa \& Ionescu, 2004). An example of strategic dashboard is presented in Figure 3.

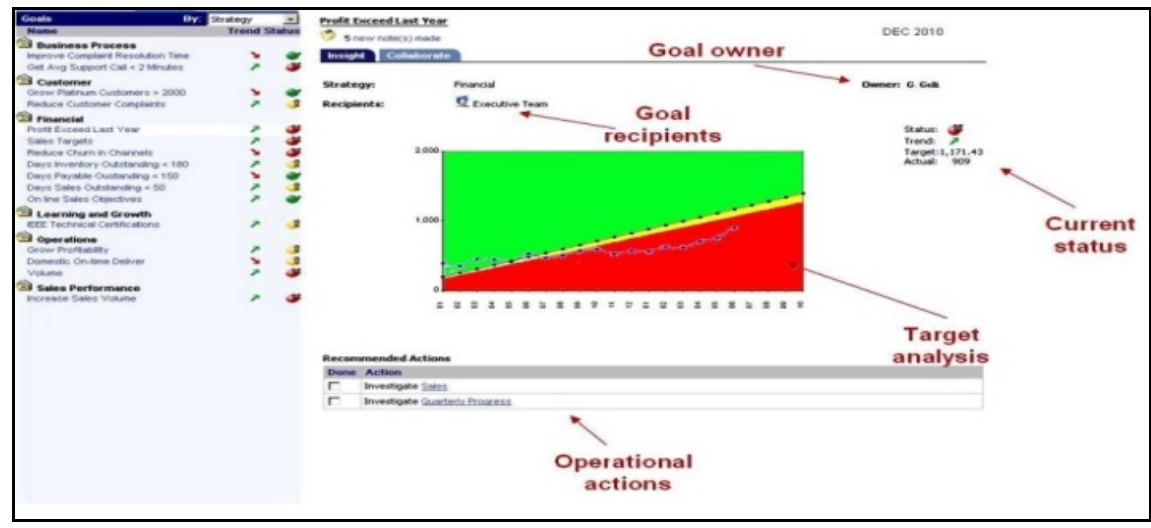

\section{Figure 3 An example of business intelligence strategic dashboard containing actual vs. target analysis and recommended action \\ Source: BI Dashboards, http://www.bidashboard.org/types/strategic.html}

The information supplied is used to monitor the progress of the company in achieving the preset objectives. The main performance objective of any enterprise is to ensure the economic, the social and the environmental task. In order to achieve this objective, certain other derived objectives must be achieved first: ensuring the sustainable economic performance of the company, by means of managing simultaneously the levels of uncertainty for the future; meeting the needs and the expectations of those interested by creating value for parties concerned; ensuring the sustainable development. The parties concerned with the achievement of these objectives are: the shareholders, the clients, the users, the enterprise itself, the partners, the employees, the collectivity, the result aimed at being to create value. 
Tactical dashboards give more details on the information listed in the strategic dashboards, in order to identify the trends in relation to the objectives and the initiatives of the company. There are many factors and values which could be measured by these dashboards, but all of them are reported to the preset objectives. An example of tactical dashboard is presented in Figure 4.

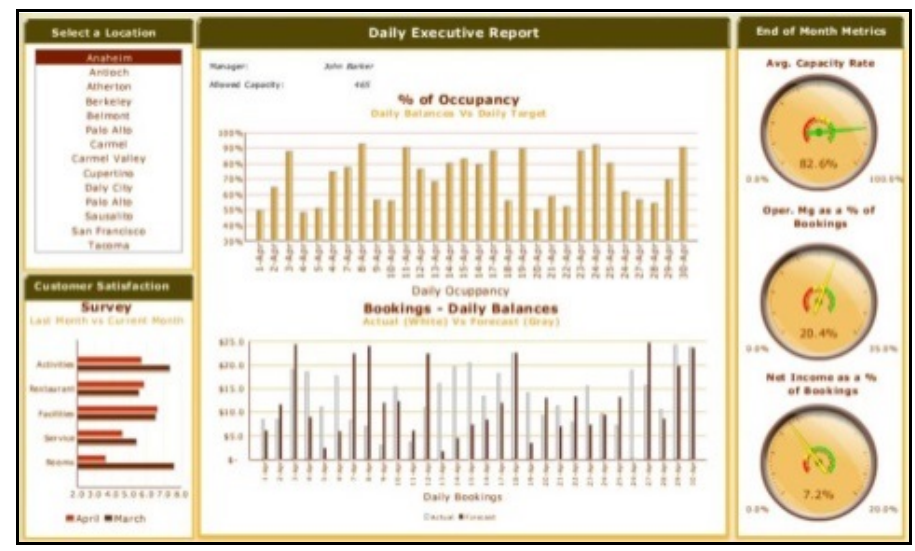

\section{Figure 4 An example of business intelligence tactical executive dashboard in a hotel network \\ Source: BI Dashboards, http://www.bidashboard.org/types/tactical.html}

Tactical dashboards are drafted for tactical purposes, for monitoring the actions taken within the departments, the projects, the geographical areas, etc. Situated on an intermediary strategic level, the tactical dashboards have the role to facilitate the link between the strategic and the operational levels.

Operational dashboards. Unlike the strategic and the tactical dashboards which are conceived for and addressed exclusively to the managers, the operational dashboards are used on operational level (departments) and are addressed to the employees within these departments, seldom to the managers. These dashboards must allow the data analysis, following the history of the data, and based on the information gathered those concerned could make decisions which should lead to the improvement of the present situation. An example of operational dashboard is presented in Figure 5.

No matter the level on which it is drafted, the information included in the dashboard should be:

- consistent, which means relevant, synthetic and accurate concerning the field in question;

- accurate, meaning that they should highlight the economic phenomena and send the information in real time;

- synthetic, with different degrees of aggregation according to the hierarchic level of the beneficiary;

- accessible, easy to grasp, clear, explicit;

- balanced, highlighting the economic phenomena according to their weight in that particular field;

- expressive, presented as suggestively as possible by means of tables, charts;

- adaptable, meaning that they should be easily adjusted according to the modifications occurring in the company's activity;

- economical, meaning that they should reflect the effects achieved compared to the efforts made. 


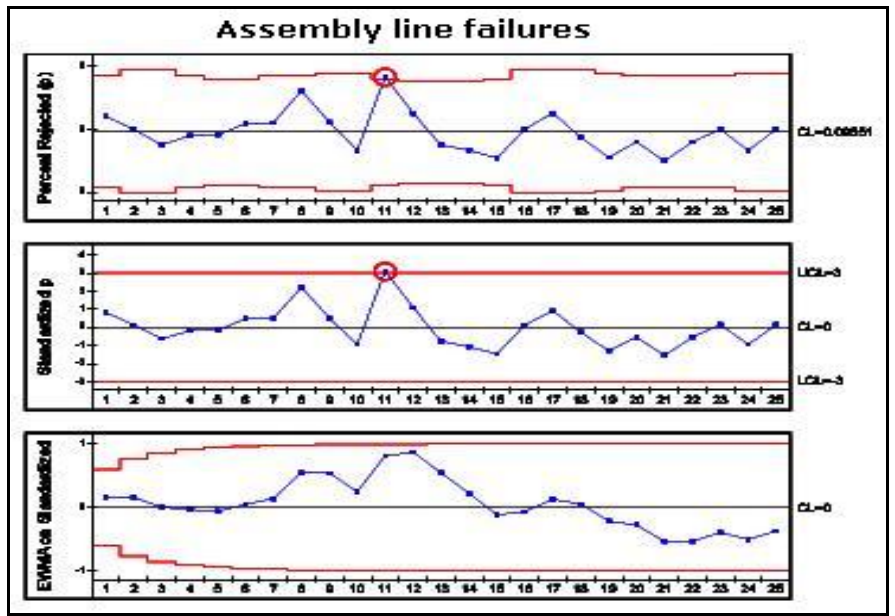

Figure 5 An example of an operational dashboard for a car manufacturer Source: BI Dashboards, http://www.bidashboard.org/types/operational.html

The tool which is most frequently used in drafting dashboards is Microsoft Excel, although there are over 50 software products available. Excel has the advantage of being a familiar tool, easy to use for drafting, with quick results in a short period of time.

\section{Performance control by means of the dashboard}

The control by means of the performance dashboard implies the definition of the performance and pilotage indicators. By means of performance indicators we can measure the level of performance achieved, while the pilotage indicators set the level to which the action plan has advanced. The place of the dashboard in the control process is presented in Figure 6.

There is a close connection between the two categories of indicators. From this point of view, the dashboard becomes a working tool. Four situations may occur connected to these indicators (see Figure 7).

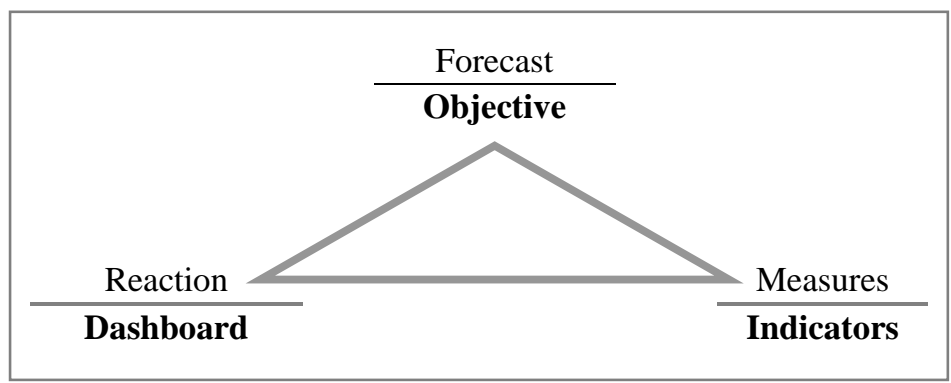

Figure 6 The place of the dashboard in the control process

Source: Caraiani, C., Dumitrana, M. (coord.) et al (2005), Contabilitate de gestiune şi control de gestiune, InfoMega Publishing House, Bucharest, p. 438 


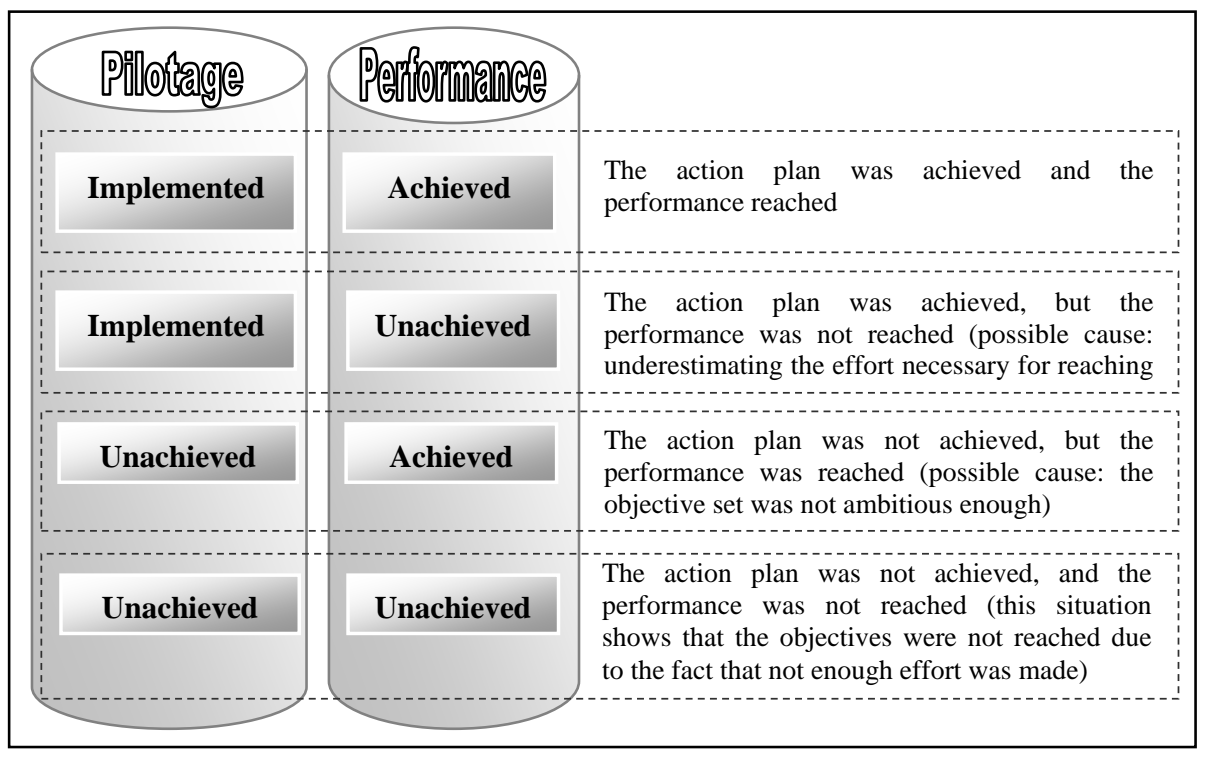

Figure 7 The connection between the pilotage and the performance indicators Source: by author

The indicators chosen must be accurate and objective, must vary just as the phenomenon subjected to the measurement, must have identical significance in time and space, they have to be quickly calculated and able to be synthesized when passed to a higher level in the chain of command (Albu \& Albu, 2003).

According to their role, the indicators can be:

- warning indicators $>$ - they signal an abnormal state;

- balance indicators - they highlight a normal state;

- anticipation indicators pars preser future - they predict and anticipate possible operational trends, changes, decisions.

In order to ensure coherence and visibility to the system of indicators in the dashboard, they can be:

- financial indicators;

- activity indicators;

- cost measuring indicators;

- profitability indicators;

- productivity indicators;

- specific indicators.

The indicators must show the results of the actions:

- formal results- they imply comparing the achievements with the predicted data;

- derived results - they are the unpredicted consequences of he actions involved;

- implicit results - they lead to the modification of the competition game, referring to the strategic information.

The dashboards can be drafted and developed in order to meet a large range of requirements, starting from monitoring the strategic level of the enterprise, and extending to monitoring and controlling the achievement of the operational objectives on the level of each department. In other words, in conceiving the dashboard we must take into consideration the stages of the management process: formulating the strategy (strategic objectives), planning the means for applying the strategy suggested, assigning the resources, drafting the budgets, the action, the reports, the monitoring, 
the control and the result analysis. Most types of dashboards existing on the market take into consideration the stages of the management process until the monitoring stage inclusively. However, the importance of the analysis stage has been reckoned nowadays, and consequently it started to be included in the enterprise dashboard (see Figure 8).

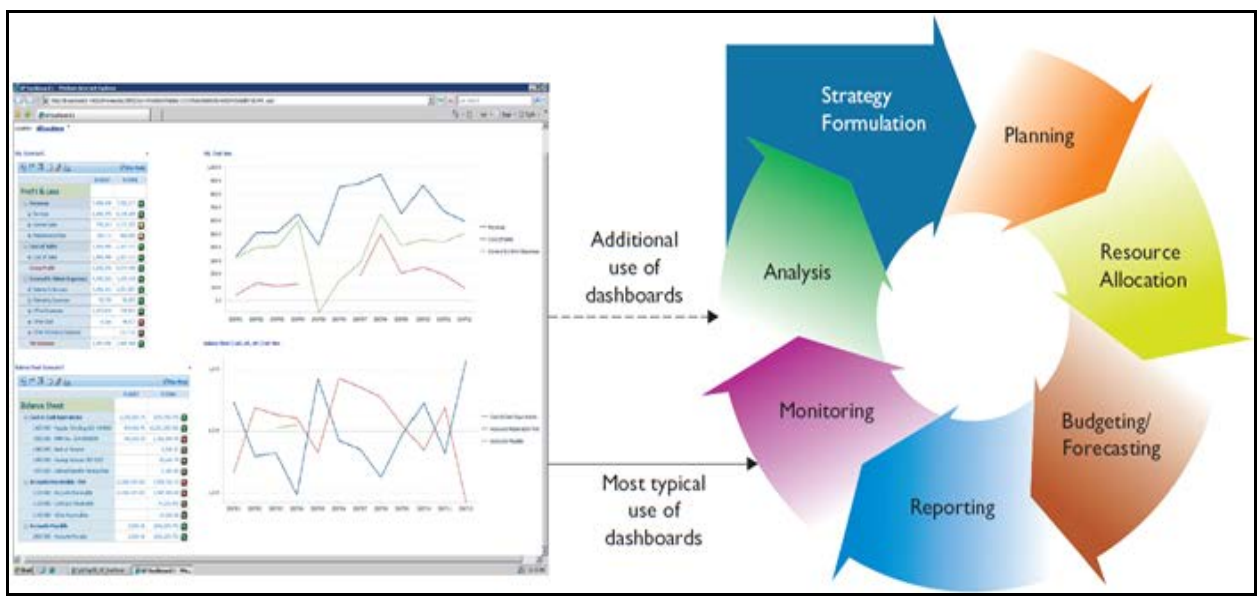

Figure 8 Dashboards and Performance Management

Source: http://www.dashboardinsight.com/articles/digital-dashboards/fundamentals/dashboards-role-in-abusiness-intelligence-solution.aspx

The studies performed (Kawamoto \& Mathers, 2007), which aimed at highlighting the real requirements of the users in the economic field concerning the building/design/offer of information included in the dashboard identified a series of key success factors:

- a dashboard must be easy to draft with minimum effort, must have a logical structure and offer quick results;

- defining certain measures using business terms relevant for the parties concerned, which should supply a mixture of operational, financial and company specific data;

- the dashboard should be a tool meant to facilitate the management process;

- the dashboard should allow revising and changing the data as often as necessary, according to the economical changes and to the new business conditions (requirement which proved to be the most difficult to meet).

From the data presented above, it follows that the performance dashboard is a set of informational elements which should lay the foundation for the decisions made by the company managers, its role being to measure the distance covered, as well as to put into practice the action programmes while taking corrective measures in order to achieve the desired objectives (Muntean, 2006). Thus, the purpose of the dashboard as a management tool lies in reaching the preset objectives.

The dashboard, due to the information it supplies, to the way it is drafted and built as well as to its design, must allow the assessment and the management of performance using the ways of progress set in the strategy, must be a tool for the performance management that should keep up with the changes and the challenges in the current economic context. 


\section{References}

Albu, N., Albu, C. (2003), Instrumente de management al performanţei, Vol. II Control de gestiune, Economic Publishing House, Bucharest.

Caraiani, C., Dumitrana, M. (coord.) et. al. (2005), Contabilitate de gestiune şi control de gestiune, InfoMega Publishing House, Bucharest.

Fernandez, A. (2008), Les nouveaux tableaux de bord des managers. Le projet décisionnel en totalité, on the Edit Organisation, 4 th édition, available on http://www.nodesway.com/methode/methode_GIMSI_concevoir_le_tableau_d e_bord.htm.

Dragomirescu, S. E. (2013), Control de gestiune. Curs universitar, Alma Mater, Publishing House, Bacău.

Dumitru, M., Calu, D. A. (2008), Contabilitatea de gestiune şi calculaţia costurilor, Contaplus Publishing House, Ploieşti.

Kawamoto, T., Mathers, B. (2007), Key Success Factors for a Performance Dashboard, available on http://www.dashboardinsight.com/articles/digitaldashboards/fundamentals/key-success-factors-for-a-performancedashboard.aspx.

Muntean, M. (2006), Analiza echilibrului economico-financiar al întreprinderilor comerciale, EduSoft Publishing House, Bacău.

Popa, V., Ionescu, A., (2004) Generarea şi folosirea unor modele de performanţă organizaţională: tabloul de bord strategic global (TBSG) şi tabloul de bord echilibrat (TBE), available on http://www.ecr-uvt.ro/informatii_noutati/pdf/ Sesiune_de_comunicari_J.M. JURAN'/TBSG.pdf.

Robu, D. M. (1998), Controlul de gestiune pe baza de bilanţ, Moldova Publishing House, Iaşi.

Solomon, D. C., Tataru, S. E. (2007), Consideraţii privind valorificarea informaţiei contabile în aprecierea performanţei întreprinderii, Volume Contabilitatea în contemporaneitatea românească, Editura EduSoft, Bacău, pp. 229-238.

Tabără, N., Tataru, S. E. et. al. (2009), Control de gestiune. Delimitări conceptuale, metode, aplicaţii, TipoMoldova Publishing House, Iaşi.

Tataru, S. E., Solomon, D. C. (2007), Tabloul de bord - sistem de control al performanţei întreprinderii, Volume Contabilitatea în contemporaneitatea românească, EduSoft Publishing House, Bacău.

Tataru, S. E., Solomon, D. C. (2008), Performance measurement - an attribute of management control, Simpozionul ştiinţific internaţional "Economie europeană: prezent şi perspective - Dimensiunea economico-juridică a integrării României în structurile europene şi euro-atlantice”, VIII-th edition, Suceava, Volume 4, pp. 143-146. 